Proceeding of

2018 12th International Conference on Telecommunication Systems, Services, and Applications (TSSA)

October $4^{\text {th }}-5^{\text {th }}, 2018$

Grand Mercure Adi Sucipto,

Yogyakarta, Indonesia

ISBN (XPLORE COMPLIANT): 978-1-5386-6940-2 


\section{Copyright and Reprint Permission}

Abstracting is permitted with credit to the source. Libraries are permitted to photocopy beyond the limit of U.S. copyright law for private use of patrons those articles in this volume that carry a code at the bottom of the first page, provided the per-copy fee indicated in the code is paid through Copyright Clearance Center, 222 Rosewood Drive, Danvers, MA 01923. For reprint or republication permission, email to IEEE Copyrights Manager at pubs-permissions@ieee.org.

All rights reserved. Copyright (C2018 by IEEE. 


\section{Table of Contents}

THE EFFECT OF LATENCY ON SELFISH MINER ATTACK ON BLOCK RECEIVETIME BITCOIN NETWORK USING NS3

Bellia Dwi Cahya Putri and Riri Fitri Sari

\section{FORECAST OF SPECTRUM REQUIREMENT FOR MOBILE BROADBAND}

Irsyad Ridwany and Iskandar

Design and Implementation of Real-time Object Tracking System based on Viola-Jones Algorithm for Supporting Video Conference

Bangsa Edwiranda, Bryan Christy Purba and Yoanes Bandung

Design and Implementation of WebRTC-Based Video Conference System in Odroid Board

Bryan Christy Purba, Muhammad Diva Pasha and Yoanes Bandung

Home-Scale Vertical Axis Wind Turbine Design

Rini Handayani, Anak Agung Gde Agung, Marlindia Ike Sari and Naufal Mudhoffar Sastradikusumah

Planar Array Antenna with Radiation Pattern Reconfigurability Using PIN Diode

Sitia Gamawati Erta Lestari and Achmad Munir

A Comparison Application of the Genetic and Steepest Ascent Hill Climbing Algorithm in the Preparation of the Crossword Puzzle Board

Yoppy Sazaki, Anggina Primanita, Hadipurnawan Satria and Rezi Apriliansyah

Performance Analysis of Microstrip Circular Patch Antenna Composed of Artificial Dielectric Material Hepi Ludiyati, Yugyta Prafitri, Rheyuniarto Sahlendar Asthan and Achmad Munir

SCOR and AHP Based Monitoring Dashboard to Measure Rice Sourcing Performance at Indonesian Bureau of Logistics

Muhammad Fadil Novar, Ari Yanuar Ridwan and Budi Santosa

Design and Study of Rectangular Patch Antenna Array for High Altitude Platform Station Ryan Fikri, Muhammad Ammar Wibisono and Iskandar

Differentially Proximity Coupled Ring Printed Antenna Array For L-Band SAR Application Rheyuniarto Sahlendar Asthan and Achmad Munir

E-Key Prototype Implementation Based on Short Message Service (SMS) Technology

Lia Kamelia, Eki Ahmad Zaki Hamidi and Akhmad Jazuli Baskara

SR-Based Printed Antenna Array with Reduced Size

Mochamad Yunus, Yamato Tan and Achmad Munir

Analysis of SIW BPF Performance Influenced by Number of CSRRs Incorporation

Rusdi Affandi, Nanang Ismail, Hardi Nusantara and Achmad Munir

$2100 \mathrm{MHz}$ Spectrum Refarming In Indonesia

Mohammad Ridwan Effendi and Adis Alifiawan

Design And Realization of Low Noise Amplifier at $3 \mathrm{GHz}$ Frequency for T/R Module Eki Ahmad Zaki Hamidi, Agus Wandi Sholihuddin and Yana Taryana 
Forensic Analysis of Android-based Instant Messaging Application

Imam Riadi and Arizona Firdonsyah

Thin Clients as Memoryless Computer for Reducing Digital Divide in East Indonesia

Rini Handayani and Gaous Afrizal

The Calculation of Gyroscope Sensor Angles Using Several Integral Methods

Nanang Ismail, Abdurrahman Nurhakim and Hendri Maja Saputra

Development of E-Marketplace in Department of Agriculture Food Crops and Horticulture as a Means to Expand The Market of Processed Food

Rusydi Umar, Jefree Fahana and Agus Triyono

Miniaturization of 2.4GHz SIW Antenna Using Complimentary Split Ring Resonator

Ade Saputra, Nanang Ismail, Mochamad Yunus and Achmad Munir

IoT Based Organic Waste Burner for Wood Vinegar Production

Yamato Tan, Mochamad Rizky Rahmadi, Evyta Wismiana, Mochamad Yunus and Achmad Munir

DEVELOPMENT OF MONITORING REVERSE LOGISTIC SYSTEM FOR LEATHER TANNING INDUSTRY USING SCOR MODEL

Rangga Yudhista Kuswandi, Ari Yanuar Ridwan and Rosad Ma'ali El Hadi

DEVELOPMENT OF CYCLE COUNTING MONITORING DASHBOARD WITH BUFFER TIME

MANAGEMENT FOR COCOA COMPANY

Eriko Mahtamtama, Ari Yanuar Ridwan and Budi Santosa

Scrum Implementation for Online Transaction Processing (OLTP) in Hospital Management

Tedy Setiadi and Syauqi Bima Premapasha

Implementation of Information Retrieval Using Tf-Idf Weighting Method On Detik.Com's Website Arfiani Nur Khusna and Indri Agustina

SIMILARITY DETECTION OF STUDENT ASSIGNMENTS USING ROCCHIO METHOD

Dewi Soyusiawaty, Anna Hendri Soleliza Jones and Panggah Widiandana

Book Data Content Similarity Detector With Cosine Similarity (Case study on digilib.uad.ac.id)

Dewi Soyusiawaty and Yahya Zakaria

Feature Selection with Combination Classifier use Rules-Based Data Mining for Diagnosis of Coronary Heart Disease

Dwi Normawati and Sri Winiarti

Tomography Image Reconstruction using Parallel-Beam Projection at Microwave Frequency Ricky Willyantho and Achmad Munir

The Implementation of K-Means Clustering Method in Classifying Undergraduate Thesis Titles Lisna Zahrotun, Nila Hutami Putri and Arfiani Nur Khusna

Marketplace Seller Recommender with User-Based Multi Criteria Decision Making

Murein Miksa Mardhia and Dwi Normawati

Utilization of the Gesture Library For Learning Java Characters Interactive

Nur Rochmah Dyah Puji Astuti, Ika Arfiani and Doni Nur Laksono 
Circular Waveguide Array for Radio Frequency Energy Harvesting

Muhammad Panji Kusuma Praja, Mohammad Sigit Arifianto and Achmad Munir

ASYMMETRIC CARRIER AGGREGATION ON LTE-ADVANCED ACCESS NETWORKS

Nivika Tiffany Somantri and Iskandar Iskandar

A Simulation of Cache Replacement Strategy on Named Data Network

Hamonangan Situmorang, Nana Rachmana Syambas, Tutun Juhana and Ian Yosef Matheus Edward

Performance analysis of OFDM system augmented with SC diversity combining technique in presence of $\mathrm{CFO}$

Aanchal Jhingan, Lavish Kansal, Gurjot Singh Gaba, Faisel Tubbal, Suhila Abulgasem

BER analysis of GFDM system augmented with SC diversity combining scheme for diverse Pulse

Shaping Filters

Pawan Kumar, Lavish Kansal, Gurjot Singh Gaba, Mohamed El Bakkali, Faisel Tubbal, Suhila

Abulgasem

Overhead of Named Data Networking Routing Protocol

Tody Ariefianto Wibowo, Nana Rachmana Syambas and Hendrawan Hendrawan

Application Analysis of Bandwidth License Fee for Point-To-Point Microwave Link Radio

Communication System

Denny Setiawan, Irwan Salim, Cahya Budi Muhammad and Anna C. Situmorang

Assessment of IT Governance of Bakti Internet Access Program Based on the COBIT5 Framework

Raditya Muhammad and Ian Yosef Matheus Edward

Error Pointing Correction System Implemented in the Air Balloon Communication System

Hervin Hidayat, Muhammad Ammar Wibisono, Ryan Fikri, Siti Maria Ulfa and Iskandar Iskandar

The Decision Accuracy of Acquaintance List from Different Risk-cost Analysis

Yudha Purwanto, Kuspriyanto Kuspriyanto, Hendrawan Hendrawan and Budi Rahardjo

ROI Based Post Image Quality Assessment Technique on Multiple Localized Filtering Method on Kinect Sensor

Kholilatul Wardani, Aditya Kurniawan, Eueung Mulyana and Hendrawan Hendrawan

Sum Rate of Massive MIMO Systems Deploying Uniform Circular Planar Array Base Station Antenna Irma Zakia

Leveraging SDN for Handover in Distributed Mobility Management of 5G Network

Rifqy Hakimi, Harashta Tatimma Larasati, Alvin Mustafa and Abdallah A. Abu-Arabia 


\section{Development of E-Marketplace in Department of Agriculture Food Crops and Horticulture as a Means to Expand The Market of Processed Food}

\author{
Rusydi Umar \\ Department of Informatics Engineering \\ University of Ahmad Dahlan \\ Yogyakarta, Indonesia \\ rusydi_umar@rocketmail.com
}

\author{
Jefree Fahana \\ Department of Informatics Engineering \\ University of Ahmad Dahlan \\ Yogyakarta, Indonesia \\ Jefree.fahana@tif.uad.ac.id
}

\author{
Agus Triyono \\ Department of Informatics Engineering \\ University of Ahmad Dahlan \\ Yogyakarta, Indonesia \\ files.agustriyono@gmail.com
}

\begin{abstract}
Department of Agriculture Food Crops and Horticulture has a task to develop an activity to increase the production of agriculture and horticulture, and also develop the business of food crops and horticulture. One of its partner to do the task is Aspemako. Aspemako is an association of business of processed food. In this paper we take a case in Gunung Kidul District. Currently in marketing part, the Aspemako puts its products in a tent in front of the Department, so the market is very small and the business becomes sluggish. In that way Aspemako needs a new means to expand the market to increase their business. The development of the e-marketplace follows water fall process model, like analysis, design, implementation and testing. From the testing it is sure that the e-marketplace is running well and it is a decent tool for Aspemako to increase the market of processed food.
\end{abstract}

\section{Keywords-e-marketplace; processed food; aspemako}

\section{INTRODUCTION}

One of the goal Department of Agriculture Food Crops and Horticulture in Indonesia is to develop a sustainable activity to increase the production of agriculture and horticulture, to make a good product of food corps and horticulture and also develop the business of food crops and horticulture [1]. In this paper we take a case of Gunung Kidul District. One of its partner to achieve the goal is Aspemako. Aspemako is an association of business of processed food. Aspemako in Gunung Kidul District currently has 60 member. All of them doing a business of processed food. Every Friday morning Aspemako opens a traditional market of processed food in front of Department of Agriculture Food Crops and Horticulture office, to sell their processed food [2]. In that way their turnover is limited, because the consumer are only from its surrounding neighborhood. Their processed food has a specific taste and has a potential to be sold in the global market.

From that situation, we can say that actually, Aspemako and Department of Agriculture Food Crops and Horticulture together needs a means to increase their business and hence their turnover. Electronic marketplaces (e-marketplaces) are examples of new business practices that have emerged to facilitate specific e-commerce processes. E-marketplaces are commonly defined as a central marketplace connecting buyers and suppliers (or sellers) electronically to facilitate exchanges of information, goods and services [3].

Daniel, E M, Hoxmeier, J. White, A, Smart, A [4] have proposed a framework that describes the factors that influence the sustainability of e-marketplaces. These factors are the macroeconomic and regulatory level, the industry level, the individual firm level. Xiaoping, Z, Chunxia Wu, Dong Tian, Xiaoshuan Zhang [5] have conclused that B2B E-Marketplace process in agriculture product marketing can be analyze the benefit and critical factors in problem agriculture marketing. Agung [6] has made an application for buying and selling on e-marketplace. It has features for a buyer like shopping cart, multi transaction, and refund. For a seller it has features like processing product, processing transaction, statistic, and payout. For administration, it has feature like registration for buyer and seller, moderation processing refund and payout. Rudi [7] has made an emarketplace for online auction, it has features like searching a product offering (offer to buy and offer to sell). Novaldy [8] has made an e-marketplace that has a feature like buyer can buy from a different seller with a single payment. Bukalapak [9] is an application of e-marketplace for public, anyone can joint Bukalapak as a buyer or a consumer. They can sell anything an also they can buy anything. Bukalapak, one of the biggest marketplaces in Indonesia, facilitates about IDR 500 million $(\$ 41,000)$ worth of transactions every day in 2014 [10]. In particulari, Janita and Miranda [11] said that recognize e-marketplace is no easy task for managers to attain a competitive advantage that will endure over time. they has identified four key factors in maintaining a high-quality level, managers of B2B e-marketplaces should pay special attention: reliability and security, the usefulness of the information provided, value-added services, and efficiency.

From the above explanation, it is clear that there is not yet marketplace for Aspemako that is exclusive for processed 
food from Gunung Kidul District. This paper will talk about the development of e-marketplace in Department of Agriculture Food Crops and Horticulture as a means to Expand the market of processed food in Gunung Kidul District.

\section{REQUIREMENT ANALYSIS}

In this part we will talk about requirement analysis for emarketplace in Department of Agriculture Food Crops and Horticulture as a means to Expand the market of processed food in Gunung Kidul district.

\section{A. User Requirement analysis}

- Administrator of the e-marketplace has an access to all data, so that he can control all the system. Administrator for this e-marketplace is Department of Agriculture Food Crops and Horticulture.

- Seller, is a member of Aspemako who's already registered in the system. He/She can do processing product, order, and delivery of the product.

- Buyer, has an ability to search a product, has a shopping cart, confirmation of payment, and see the status of shipment.

\section{B. System Requirement Analysis}

- Functional requirement like login, processing member, product, order, payment, and shipment. It also has a forum to communicate between all the registered user.

- Nonfunctional requirements like it can be used with any browser, can be accessed by anyone from anywhere and anytime

\section{DESIGN}

Design of e-marketplace in Department of Agriculture Food Crops and Horticulture in Gunung Kidul follows object oriented design, so it has use case diagram, activity diagram, sequence diagram. Use case diagram of e-marketplace in Department of Agriculture Food Crops and Horticulture as a means to expand the market of processed food in Gunung Kidul can be seen in Figure 1.

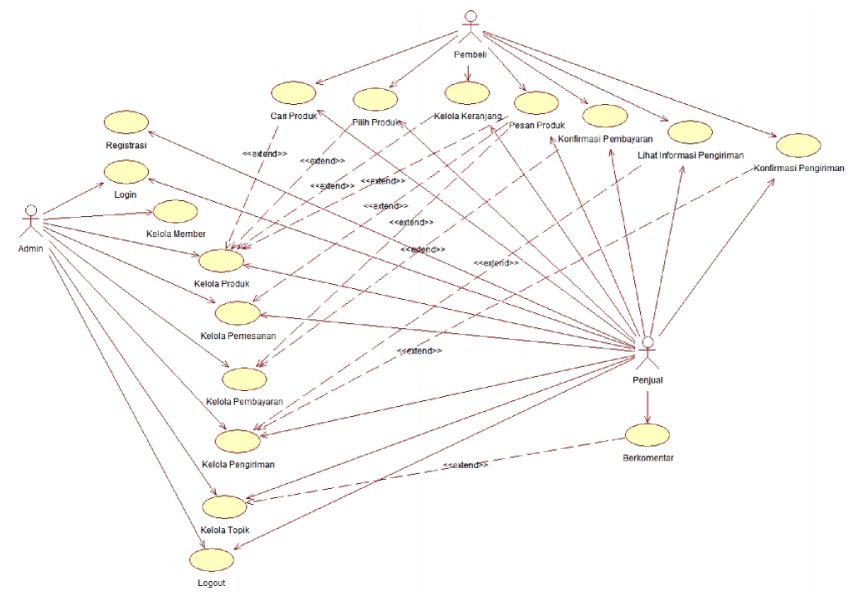

Figure 1. Use Case Diagram

From Figure 1, we can see three actor which are administrator, seller and buyer. Every actor has a different access rights. Administrator can do login, managing member, manage product, order, payment, shipment, topic in forum, and logout. Seller can do registration, login, managing product, order, topic in forum, shipment and logout. Buyer can do searching a product, managing shopping cart, ordering product, confirming payment, and shipping.

Activity diagram is modelling the workflow of business process and the sequence of the activity in the process. Activity diagram also helpful for describing parallel behavior, or describing the interaction of several use case. According to the use case diagram we will have 15 activity diagrams, due to the limited space we are not putting them in this paper.

Sequence diagram describe interaction between object in time sequence. It can be used to show the message that is passed between object. 15 sequence diagrams, due to the limited space we are not putting them in this paper.

The design of database uses entity relationship diagram (ERD). ERD of e-marketplace in Department of Agriculture Food Crops and Horticulture in Gunung Kidul can be seen in Figure 2.

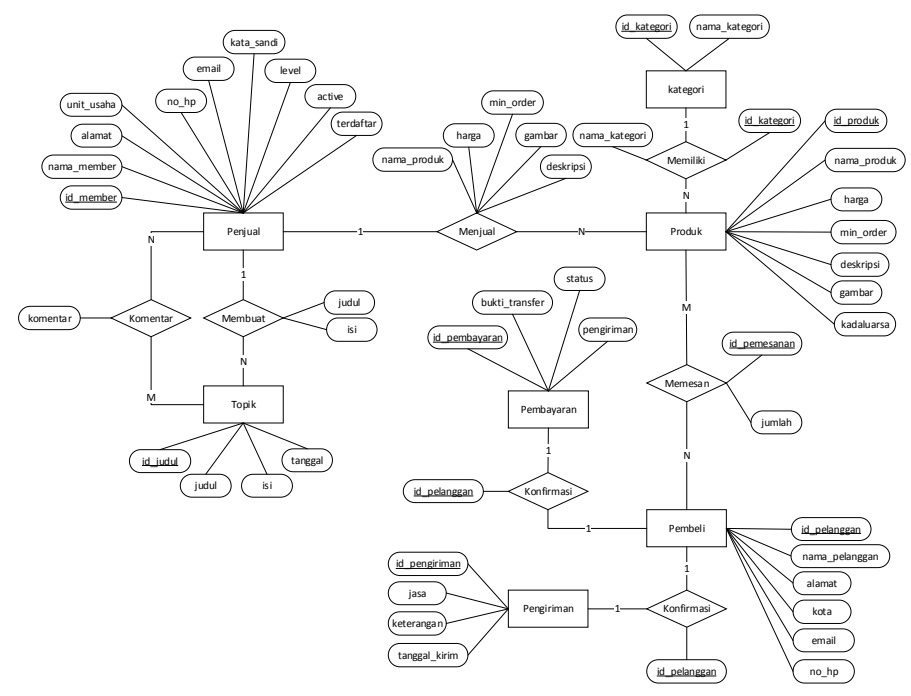

Figure 2. Entity Relationship Diagram (ERD)

\section{IMPLEMENTATION}

In implementation we use PHP with framework CodeIgniter (CI), HTML, and for database we use MySQL. We will not show all the screenshot of the application, but only some of them which are:

\section{A. Searching Page}

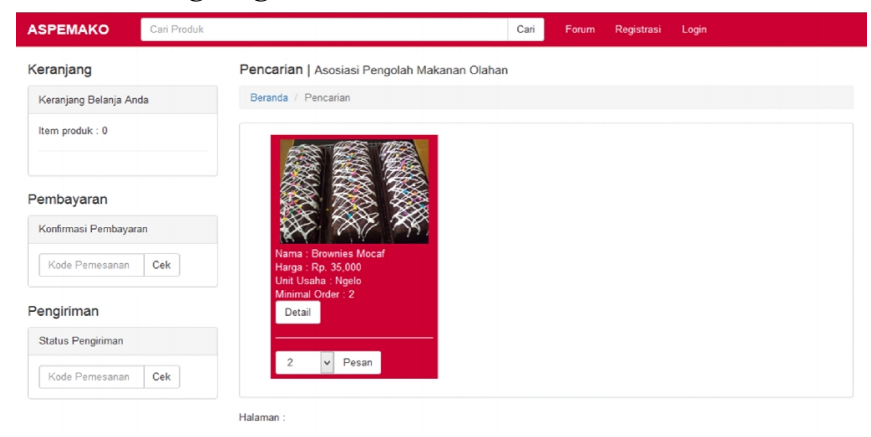

Figure 3. Searching Page 
Figure 3, shows the screenshot of searching page. User can search the product they want to see and buy. User can input the searching key and the system will display the the result. Figure 4, shows the screenshot of manging the shopping cart. Users can manage their shopping cart like add item, delete item and clear the shopping cart.

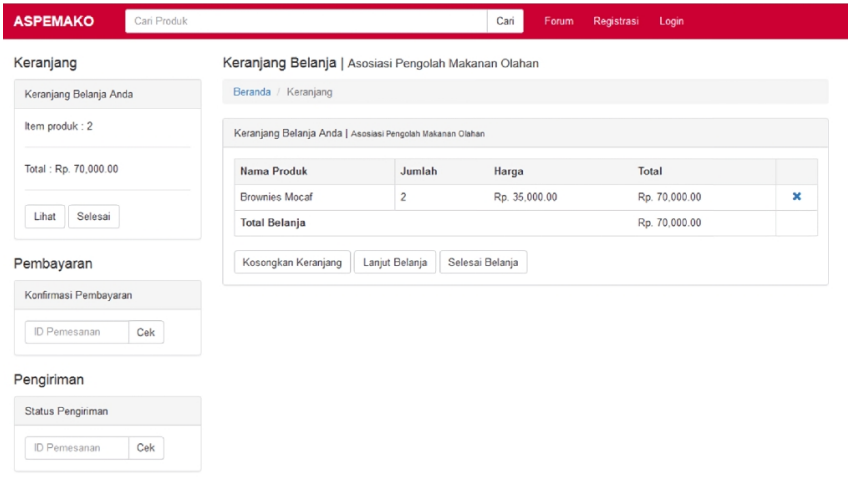

Figure 4. Manage the shopping cart

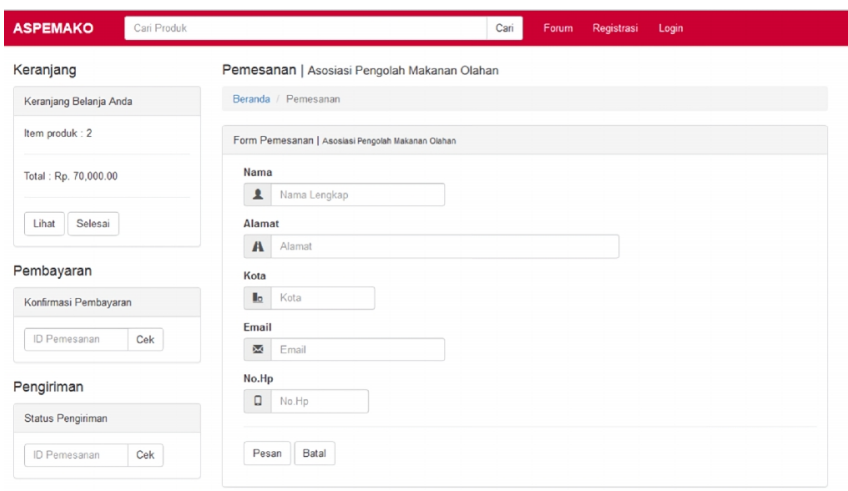

Figure 5. Order Page

The order page can be seen in Figure 5. User can fill the form where the product has to be shipped. The payment confirmation page can be seen in Figure 6. User can upload their transfer receipt.

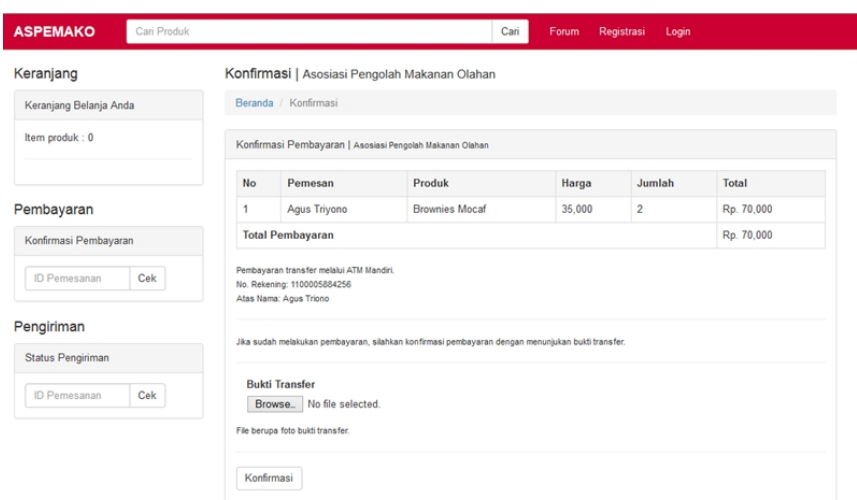

Figure 6. Payment Confirmation Page

The shipment status page can be seen in Figure 7. User can see the shipment status of their order in this page.

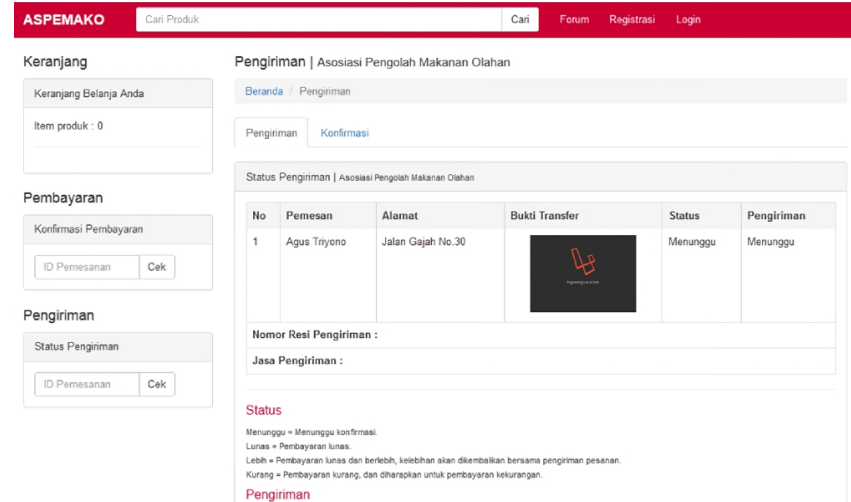

Figure 7. Shipment Satus Page

\section{TESTING}

We have done testing for e-marketplace in Department of Agriculture Food Crops and Horticulture in Gunung Kidul District with two methods. Alfa testing and Black Box Testing. Respondens to conduct Black Box Testing are Dinas Tanaman Pangan dan Holtikulura (TPH) Gunung Kidul. They are really understood about management of these system. From Black Box testing we have a result that the system is running well and no errors. Whereas Alfa Testing, involves 10 respondens from the different work backgrounds. From the Alfa testing we have a result that $95 \%$ of users agree that the system is user friendly, easy to used, nice performance, so the system is deserve to be implemented.

\section{CONCLUSION}

We have several conclusion in developing e-marketplace in Department of Agriculture Food Crops and Horticulture in Gunung Kidul District i.e:

- We have developed developing e-marketplace in Department of Agriculture Food Crops and Horticulture in Gunung Kidul District as a means to expand the market of processed food in Gunung Kidul District

- The developing e-marketplace in Department of Agriculture Food Crops and Horticulture in Gunung Kidul District is deserve to be implemented.

- This e-marketplace in Department of Agriculture Food Crops and Horticulture in Gunung Kidul District can help in Department of Agriculture Food Crops and Horticulture in Gunung Kidul District to achieve their goals.

\section{ACKNOWLEDGMENT}

This research was partially supported by Department of Informatics Engineering, Faculty of Industrial Engineering, University of Ahmad Dahlan.

\section{REFERENCES}

[1] http://pertanian.gunungkidulkab.go.id/halaman-contoh/tujuansasaran/ accessed on June 1, 2016

[2] http://gunungkidulonline.com/tiap-jumat-di-kantor-dinas-tphgunungkidul-ada-pasar-tenda-lho/ accessed on May 15, 2016 
[3] Anders and Marc, "International E-Marketplaces How do They become successful?", Master Thesis - MSc International Business, Department of Business Administration, School of Business and Social Sciences, Aarhus University, 2015

[4] Daniel, E M, Hoxmeier, J, White, A, Smart, A, "A Framework for the Sustainability of E-Marketplaces", Business Process Management Journal, 2004, 10, 3, ABI/INFORM Collection pg. 277

[5] Xiaoping, Z; Chunxia, Wu; Dong, Tian; Xiaoshuan, Zhang; "B2B EMarketplace Adoption in Agriculture", Journal of Software, Vol. 4, No. 3, May 2009

[6] M. Agung, "Aplikasi Jual Beli e-Marketplace [E-Marketplace Sales Application]" Final Project,: Faculty of Informatics, Institute of Technology Telkom, Bandung, 2013
[7] A. Rudy, "E-Marketplace Sebagai Sarana Transaksi Lelang Online [E-Marketplace as a means for online auction transaction]". Final Project, Informatics Engineering Department, Petra Chistian University, Surabaya, 2011.

[8] P. Novaldy, "Aplikasi e-Marketplace Berbasis Web 2.0 [Web 2.0 based E-Marketplace Appication]" Final Project Depatment of Information System, Universitas Palembang, Palembang 2005.

[9] www.bukalapak.com accessed June 1, 2016

[10] https://www.techinasia.com/bukalapak-2014-processes-41000transactions-day accessed May 5, 2016

[11] Janita M. Soledad, Miranda F. Javier, "Exploring Service Quality Dimensions In B2B e-Marketplaces", Journal of Electronic Commerce Research, Vol. 14, No. 4, 2013. 